\title{
Food Offerings of Ngesur Tanah Salvation in Belikurip Village, Wonogiri Regency: An Ethnolinguistic Study
}

\author{
Imam Baehaqie \\ Faculty of Languages and Arts, State University of Semarang, Indonesia \\ Email: imambaehaqie@mail.unnes.ac.id
}

\begin{abstract}
The purpose of this study was to describe the cultural significance of food offerings in ngesur tanah salvation in Belikurip Village, Wonogiri, Central Java, Indonesia using an ethnolinguistic approach. In data collection, the researcher employed observation and conversation methods which were then analyzed by the ethnographic method by utilizing the triangular meaning proposed by Lyons (1977). It discovered 10 names of food: (1) tumpeng bathok bolu, (2) tumpeng ungkur-ungkuran, (3) undur-undur, (4) tumpeng gung, (5) tumpeng krumpul, (6) tumpeng marga pakewuh, (7) tumpeng obor, (8) sekul suci, (9) samiran, and (10) jenang sepuh. The essence of the offering is the request for salvation for the departed soul and for the family left behind. The results of this study indicate that the use of language (food names) reflect a cultural phenomenon, namely the religious system of offerings from individuals who believe that the deceased's spirit remains alive and is fully responsible for his or her actions while living in the world. There also appears to be acculturation with other beliefs and religions.
\end{abstract}

Keywords: salvation; ngesur tanah; Javanese; ethnolinguistic; triangular meaning of Lyons

\section{INTRODUCTION}

The use of language can convey the identity of the speaker (the expression of identity). In turn, a community can be identified through the language spoken (Crystal, 1997: 4). In line with this view, Djawanai (2009: 2) stated that language is a sign system used as a symbol to represent human thoughts, concepts, and experiences. This idea could be exemplified in the language used in the food names in the offerings of salvation in Belikurip Village, Baturetno District, Wonogiri Regency, Central Java, Indonesia.

Ngesur tanah refers to the salvation required to escort a deceased body from the mortal state to the afterlife; in this case, humans come from the ground and return to the ground (Nayati et al., 2016: 444). The salvation ceremony is held on the death day (in Javanese: seda) of a person and is the first part in a series of death salvation rites that include ngesur tanah (burying the corpse on the death day), nelung dina (death memorial on the third day after the death), mitung dina (on the seventh day), matang puluh (on the $40^{\text {th }}$ day), nyatus (on the $100^{\text {th }}$ day), mendhak siji (death memorial on the first year), mendhak loro (on the second year), nyewu (on the thousandth day), ngluntur (death memorial after five years), and haul (death memorial annually).

For Javanese people, the salvation of death (seda pengetan ceremony) is the last phase of salvation of the life cycle or the rites of passage (Gennep, 1984), which include birth salvation, marriage salvation, and salvation/ memorial of death.

The language (lexicon, pronunciation, and grammar) used to speak about these concepts is more than just a tool to convey thoughts and perceptions. Someone's language has implications for the user's view of the world (Wierzbicka, 1997: 5, 10; Leavitt, 2006: 47-48). This notion is in line with the opinion of Kramsch (1998: 3), who said that, when language is used in the context of 
communication, it is intertwined with culture in complex ways. Furthermore, Kramsch stated that (1) language expresses cultural reality, (2) embodies cultural reality, and (3) symbolizes the cultural reality of its speakers.

Language and culture could be likened to a piece of paper that has two sides: the front side as language and the back side as mind. If paper is cut, it is certainly not possible to cut one side but leave the other side intact (Mahadi and Jafari, 2012: 230).

The discussion about the relationship between language and culture is related to the work of Humboldt and the Sapir-Whorf hypothesis. Humboldt's thinking is known as linguistic determinism - the idea that language determines thought. The Sapir-Whorf hypothesis combines linguistic determinism (language determines thought) with linguistic relativity (there is no limit to the structural diversity of languages). Sapir (1921: 2017) emphasized that "language does not exist apart from culture, that is, from the socially inherited assemblage of practices and beliefs that determines the texture off lives."

The basic idea in the Sapir-Whorf hypothesis is that language cannot be separated from one's culture or point of view. Everyone views the world through his or her own language. The way people see the world is determined in whole or in part by the structure of their native language or mother tongue (Crystal, 1997: 15; Kadarisman, 2008: 8; Mahadi and Jafari, 2012: 233).

The food names in the salvation offerings by the Javanese people are considered to be urgent to investigate because, over time, many people - especially the younger generation-do not understand the meaning of these foods, and they feel closer to the names of foreign foods such as hamburgers, Kentucky Fried Chicken (KFC), nuggets, pizza, steak, and sukiyaki. In contrast to these foods, the names of foods in the salvation offering delivered by Javanese people contain valuable cultural meanings.

Using a name that contains the name of the food is very important. Naming is similar to stamping (Wittgenstein, as cited in Magee, 2001: 203). Giving names includes naming food offerings, which is an important process in human life because these names could be seen as signs that a society uses to classify food items, which also reflects the worldview of the believers who promote these cultural ideas (Ahimsa-Putra, 1985: 107).

It is important for the public to know about the results of this study because they shed light on moral values that could be used as a standard for strengthening identity. At the very least, the results of this study are a means for the government to document food names in the context of preserving Javanese language and cultural treasures as assets related to tourism (Marsono, 2003: 1-48). In addition, the researchers hope that these findings could help young people understand the important cultural values contained in the lexicon of food names in salvation offerings, such as togetherness and harmony of life. In the midst of an increasingly globalized era (the era of information technology and disruption), the comprehension and revitalization of traditional cultural values have become increasingly urgent issues.

As indicated by the presentation of the background of this study and the theoretical framework, this article discusses the cultural meaning of food names in salvation offerings of ngesur tanah in Belikurip Village, Wonogiri Regency, Indonesia.

\section{METHODOLOGY}

The researcher applied an ethnolinguistic approach in this research. Duranti (1997: 2) stated that ethnolinguistics is the study of language and culture, which is a major subfield of anthropology (ethnolinguistics is part of a conscious attempt to consolidate and redefine the study of language and culture as a major subfield of anthropology). Furthermore, ethnolinguistics is the study of speech and language within the context of anthropology.

The term ethnolinguistics is synonymous with ethno-semantics. Based on Palmer's view (1999: 19), ethno-semantics, or ethno-science, is the study of ways that different cultures organize and categorize certain domains of knowledge, and the food domain is no exception. Based on the opinion of Foley (2001: 3-5), through ethnolinguistics or anthropological linguistics, experts could understand culture through the language of the community in question.

The data of this research are presented in the form of a number of food names in salvation offerings in Belikurip Village, Baturetno District, Wonogiri Regency, Indonesia. Wonogiri belongs to the Solo Raya (Great Solo) area and adjacent to the Special Region of Yogyakarta, which are at the center of Javanese culture (Purwani, 2014: 3). In addition, Wonogiri is also near East Java, which influences its culture. Therefore, Wonogiri can serve as a representative of the culture of Java because it is a place of fusion between the cultures of Solo, Yogyakarta, and East Java.

The data collection was carried out by the observation and conversation method. This method was applied by observing the practice of offerings (Mahsun, 2007: 92-93, 104). In other words, the ethnographic data were drawn from participatory observation (Spradley, 
2006: ix). During the observation, the researcher took a picture of the concrete form of the object that became the reference for the food names, revealing the significance of the references of the food names in the salvation offerings. When this method was not successful, the researcher asked the participants to show the concrete forms of the intended food offerings and then took a picture of them to record and report the appearance of the offerings. Furthermore, the observation and conversation method was used to obtain the cultural meaning of the food names from the participants (Mahsun, 2007: 95-96).

In analyzing the data, ethno-science (AhimsaPutra, 1985: 110-111), or ethnographic (Ratna, 2010: 85-89), method was applied, which is a data analysis method with an understanding based on knowledge or thought that exists or is owned by the nation, the local ethnic group, or the community studied. Ethno-science is also known as cognitive anthropology, and in this case, cognitive data (mental codes) were used, and the data truly reflect ideas in the minds of the participants. Another term is descriptive semantics (or ethnographic semantics). In this case, the researcher utilized the triangular meaning proposed by Lyons (1977: 96-97), which consists of sign, concept, and significatum.

Everything described here has a meaning for the Javanese people who live in the local community.

\section{FINDINGS AND DISCUSSION}

In Javanese salvation rites, namely ngesur tanah, performed by Belikurip people, the researcher identified some food names of the offerings, as follows: (1) tumpeng bathok bolu, (2) tumpeng ungkur-ungkuran, (3) undurundur, (4) tumpeng gung, (5) tumpeng krumpul, (6) tumpeng marga pakewuh, (7) tumpeng obor, (8) sekul suci, (9) samiran, and (10) jenang sepuh. The following section contains explanations of the cultural meaning of the names of each of these foods.

\section{Tumpeng Bathok Bolu [tumpəy $\mathbf{b}^{\mathrm{h}}$ ațo? $\mathbf{b}^{\mathrm{h}}$ olu]}

In accordance with the work of Lyons (1977: 96-97), tumpeng bathok bolu [tumpən $\mathrm{b}^{\mathrm{h}}$ at ${ }^{\circ}$ ? $\mathrm{b}^{\mathrm{h}} \mathrm{olu}$ ] serves as a sign for the concept of a wish for ngrembaka (flourishing or prosperous wealth for the family who holds the salvation), bagas-waras (healthy), and ayem-tentrem (peace to all people who attend the salvation ceremony). Its significatum is the real shape of a tumpeng bathok bolu. The significatum is a concrete form of tumpeng bathok bolu. Here, the relationship between sign and significatum is indirect, but is mediated by a concept, as seen in the figure below, presented as a dashed line.

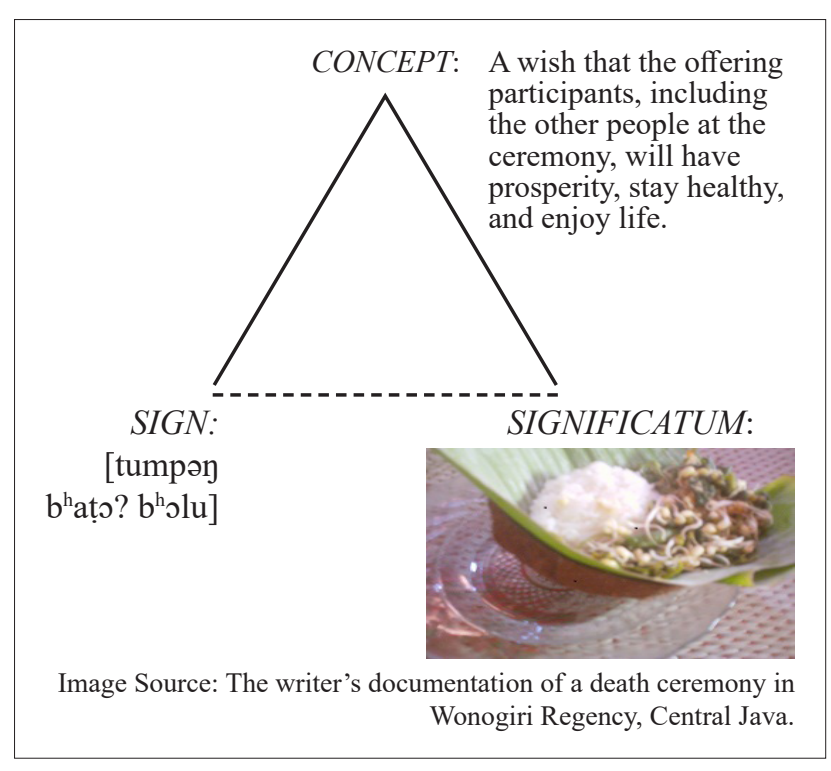

Figure 1. Sign System of Bathok Bolu.

The semiotic meaning of tumpeng bathok bolu for death memorials is different from the meaning of tumpeng bathok bolu for birth salvation rites. Tumpeng bathok bolu for birth salvation offerings is accompanied by endhok glundhung (boiled eggs); however, for death memorials, the presence of endhok glundhung is a taboo because the salvation offering presented along with endhok glundhung is seen as preventing someone's soul from going far (in Javanese: glundhang-glundhung).

According to Mr. Waridi (61 years old), an informant from Ngelosari, Jatirejo Village, Giritontro Subdistrict, tumpeng bathok bolu is a reminder for relatives left behind to be more aware and patient because one of their loved ones has died. Related to the existence of holes in the bathok bolu, although the bathok or shell is hard (in terms of giving warnings), there is still a hole (in Javanese: bolongan), which suggests there is still a way out in this life.

In addition, in the Javanese cosmological system, the use of bathok (coconut shell) from a coconut tree, which is seen to have many benefits from its roots, stems, leaves, and the fruit, also has a semiotic meaning that people living in the world should be able to emulate coconut trees. That is, wherever and whenever people are, they should be useful for others and for the universe.

\section{Tumpeng Ungkur-Ungkuran [tumpəy uykUr- uykuran]}

It is undeniable that death is the separation of the spirit from the body, which could be illustrated through many 
examples. The separation of the spirit from the body could be likened to sailors separated from their ship. Spirits with their bodies could also be likened to bright lights with their light bulbs. In this case, death is the factor that separates this light from the light bulb, leaving it without light. The separation of the spirit from the body could also be paired with the name of a salvation offering called tumpeng ungkur-ungkuran.

Tumpeng ungkur-ungkuran are cone-shaped clumps of rice that are split and placed back to back against one another. This tumpeng is made like a mountain or cone, which is then split into two sides from the tip to the base and then placed in a back-to-back position. The middle is filled with side dishes consisting of non-spicy mixed vegetables (gudhangan). Near the two opposing tumpengs, two other tumpengs are also presented, bringing the total to four tumpengs. The meaning of tumpeng ungkur-ungkuran is that the dead man has separated his spirit and body.

This salvation is intended to remind the dead person's relatives to be wholeheartedly aware without having to mourn again now that their loved one has left the world - "do not expect any more return" (aja dingenngen baline) to the world, as the person has returned to the afterlife. For this reason, relatives are kindly requested to pray for the deceased, who has left for afterlife. These tumpeng are equipped with jangan anyep ('tasteless vegetables') or non-spicy vegetables as a symbol of the journey to the realm of eternal peace and tranquility.

In addition to being a symbol of the separation of the spirit and the body, tumpeng ungkur-ungkuran could also symbolize the separation of the deceased and the living. People who have died soon begin the afterlife, while people who are still alive remain in the world. By having tumpeng ungkur-ungkuran, people hope that the dead would be forgiven of their sins and find a clear path, a spacious place, and a glorious paradise. Conversely,

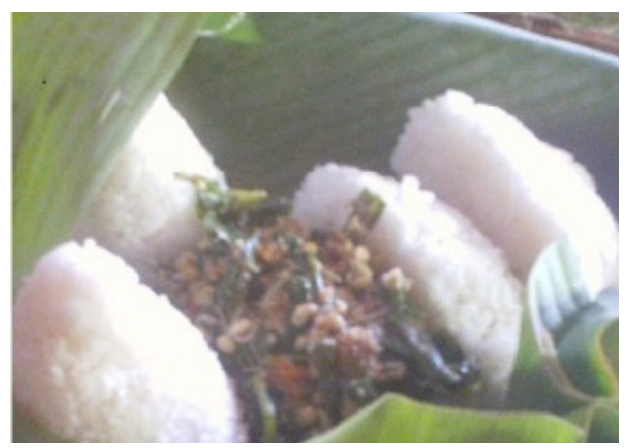

Figure 2. Tumpeng Ungkur-Ungkuran. Source: The writer's documentation of a death ceremony in Wonogiri Regency. those left are blessed with strength to live this life with rahayu wilujeng (health) and safety, with no obstacles in the way. Moreover, it is impossible for the dead to return to the living world.

Having tumpeng ungkur-ungkuran is motivated by the belief of the Javanese people in Wonogiri Regency that, if someone dies on Friday (elsewhere on Saturday), certain rites are required. Namely, the family must burn an alu 'pestle' accompanied by tumpeng ungkurungkuran so that his or her death would not spread or be contagious, meaning that no other deaths suddenly happen immediately afterward.

The people living in Belikurip highly respect those who have died. In Belik people's beliefs, the life of the deceased person up to a certain time is still around his or her family. In fact, there is a belief that people who have died could witness the actions and behaviors the living, but not vice versa, similar to how an audience can view the actors in television shows, but the actors cannot see the viewers. In addition, on certain days, the spirits of the deceased are believed to be waiting for water, which means waiting for "certain foods," such as prayers from people who are still alive.

\section{Undur-Undur [und $\mathrm{d}^{\mathrm{h}} \mathrm{Ur}-\mathrm{und} \mathrm{d}^{\mathrm{h}} \mathrm{Ur}$ ]}

Undur-undur is a kind of food that is shaped similar to the form of an antlion accompanied by side dishes of gudhangan (mixed-vegetables with grated coconut) and srundheng (grated coconut which is roasted) beside it. The semiotic meaning is ngunduri, which means avoiding or turning away from the life in the world. This food offering reminds firmly that people who have passed away have withdrawn (stopped) from the hustle and bustle of worldly affairs.

Undur-undur is a food made from rice that is formed like a cone, but the cone is made similar to the form of an antlion. The use of srundheng during the frying

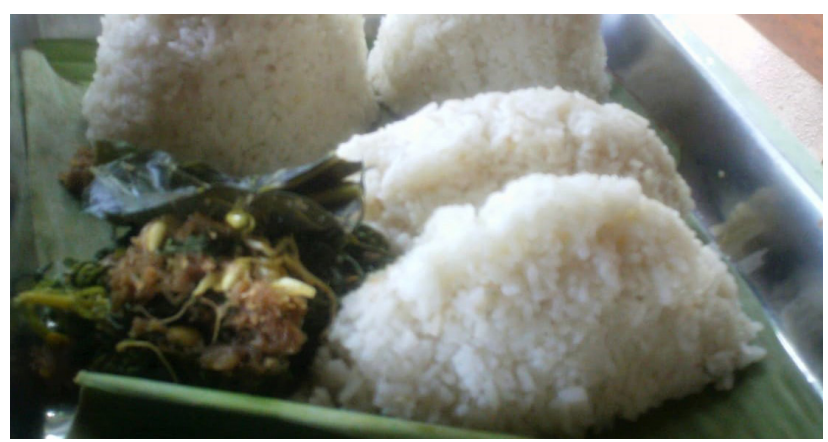

Figure 3. Undur-Undur. Source: The writer's documention of a death ceremony in Wonogiri Regency 
process creates a sweet aroma. In Javanese belief, if it has been intended for salvation, the fragrant aroma could deliver the souls of dead people to the heaven realm, which is full of pleasant things.

\section{Tumpeng Gung [tumpəy $\left.\mathrm{g}^{\mathrm{h}} \mathrm{Un}\right]$}

Tumpeng gung is a tumpeng served with eggs. It is placed on a plate on top of a bowl, and under the bowl is another plate filled with water. This tumpeng is presented only if someone dies on an even day, such as Monday Kliwon, Tuesday Legi, Monday Wage, Thursday Kliwon, Wednesday Pahing, Saturday Pon. The calculation is based on Javanese calculation; for instance, Monday (4) and Kliwon (8) equal 12 (even number). The semiotic meaning of tumpeng gung is the hope that the family left behind would always have an abundant fortune.

As described in the sub-section on the meaning, the Javanese believe that, for people who die on an even day, the salvation offerings need to be supplemented with tumpeng gung. This is in accordance with the calculation of "gunung-guntur-segara-asat," (i.e., if the calculation results in an even number, it means guntur 'thunder' and asat 'drought', so special offerings need to be made to avoid danger and a lack of fortune). Hence, the serving of tumpeng gung is related to the hope that wong sing ditinggal aja asat rezekine means that the people left behind would not lack of fortune, so their fortune would always be agung, which means abundant.

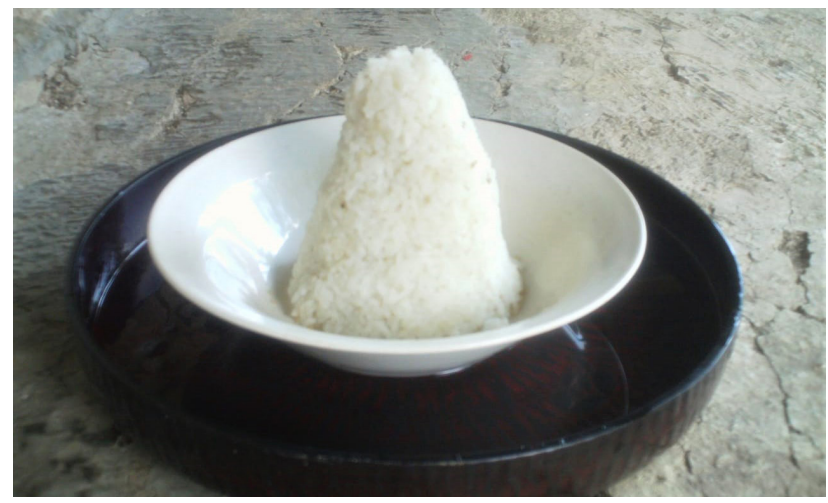

Figure 4. Tumpeng Gung. Source: The writer's documention of a death ceremony in Wonogiri Regency, Central Java

The existence of even and odd days is inseparable from petungan (Javanese calculation) related to days and pasaran (the names of Javanese days, e.g., Pon, Wage, Kliwon, etc.). Explanations of the calculation of days and pasaran could be traced in the description of Tjakraningrat (1994: 7), Gunasasmita (2009: 11-13), and Sardjananto (2009: 18-19), as displayed in the following table.
Table 1. Even and Odd Days

\begin{tabular}{|c|c|c|c|c|}
\hline No. & $\begin{array}{c}\text { Kinds of } \\
\text { Neptu }\end{array}$ & $\begin{array}{c}\text { Name of Day/ } \\
\text { Pasaran }\end{array}$ & Value & Note \\
\hline \multirow{7}{*}{1} & \multirow{7}{*}{$\begin{array}{l}\text { Name of } \\
\text { Days }\end{array}$} & Ahad 'Sunday' & 5 & \\
\hline & & Senen 'Monday' & 4 & \\
\hline & & Slasa 'Tuesday' & 3 & \\
\hline & & Rebo 'Wednesday' & 7 & \\
\hline & & Kemis 'Thursday' & 8 & \\
\hline & & Jumuah 'Friday' & 6 & \\
\hline & & Setu 'Saturday' & 9 & \\
\hline \multirow{5}{*}{2} & \multirow{5}{*}{ Pasaran } & Pon & 7 & \\
\hline & & Wage & 4 & \\
\hline & & Kliwon & 8 & \\
\hline & & Legi & 5 & \\
\hline & & Paing & 9 & \\
\hline \multirow{3}{*}{3} & \multirow{3}{*}{$\begin{array}{l}\text { Examples } \\
\text { of the } \\
\text { Calculation } \\
\text { (Day }+ \\
\text { Pasaran) }\end{array}$} & Ahad Paing & $5+9=14$ & $\begin{array}{l}\text { Even } \\
\text { Number }\end{array}$ \\
\hline & & Senen Pon & $4+7=11$ & $\begin{array}{l}\text { Odd } \\
\text { Number }\end{array}$ \\
\hline & & Slasa Kliwon & $3+8=11$ & $\begin{array}{l}\text { Odd } \\
\text { Number }\end{array}$ \\
\hline
\end{tabular}

\section{Tumpeng Krumpul [tumpən krumpUI]}

The term tumpeng krumpul was obtained from Mr. Waridi, an informant from Ngelosari, Jatirejo Village, Giritontro District. However, in another place - namely, in Giribelah, RT 2 RW 7, which still in the same village namely Jatirejo Village-a participant named Mbah Kirman (81 years old) mentioned a synonym, tumpeng kroyok. According to Widada et al. (2006: 426), the word kroyok means bebarengan wong akeh; krubut, or "togetherness."

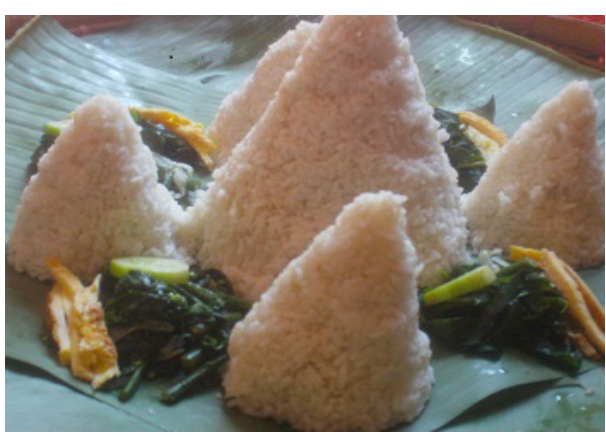

Figure 5. Tumpeng Krumpul. Source: The writer's documention of a death ceremony in Wonogiri Regency, Central Java

Tumpeng krumpul or tumpeng kroyok is tumpeng is presented together with some tumpengs on one plate. Tumpeng krumpul in Jatirejo Village, Giritontro District 
usually consist of five tumpengs, including one large tumpeng surrounded by four small tumpengs. According to Mr. Waridi (61 years old), this tumpeng is a sign of the concept of an expectation of gathering together with five forms to smoothen the journey of the deceased ("tumpeng krumpul ngumpulake sedulur papat lima wujud supados njejampangi lakune rina lan wengine"). This is expected to be a reminder of the formation of unity among fellow family members left behind.

Tumpeng krumpul becomes a sign of the concept of a hope for a gathering of sedulur papat lima wujud ('four siblings, five forms') to smoothen the journey day and night. This is expected to be a reminder of the formation of unity among fellow family members left behind. Thus, it can be implied that the unity of family members who are still alive according to the Javanese people's view, especially those living in the local community, could facilitate the journey of the spirits of the family members who have died.

\section{Tumpeng Marga Pakewuh [tumpəy margh? pakewUh]}

In line with the information collected from a participant from Ngelosari, RT 1 RW 3, Jatirejo Village, Giritontro District, Wonogiri Regency, namely Mr. Waridi (61 years old), tumpeng marga pekewuh is an ordinary tumpeng equipped with fried/sunny-side up eggs and gudhangan. This tumpeng is made so that no one prolongs the journey of the deceased spirit to the afterlife (ngewuh-ewuhi laku jantrane nyawa) so that the spirit does not stay around the family home because it would only interfere with families left behind every day, day and night (rina lan wengine).

The Javanese people (the offerers) have the belief that the spirit of the deceased would make a long journey to face God, and for certain people, it is possible to

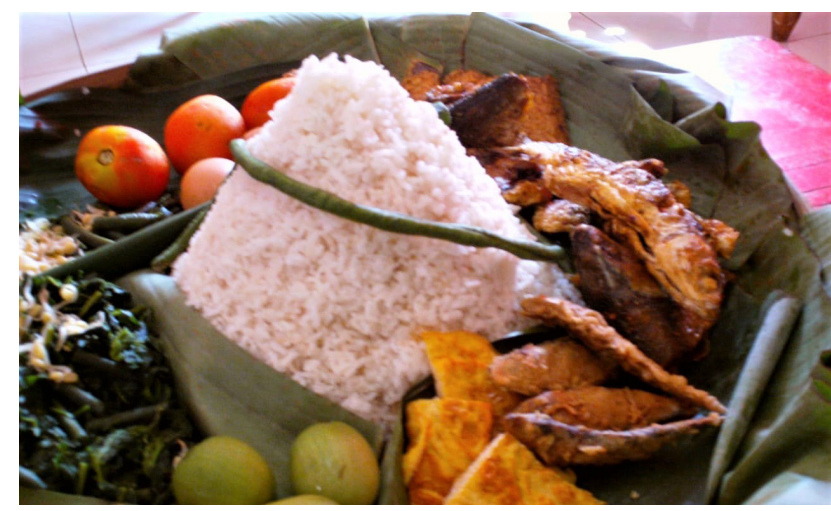

Figure 6. Tumpeng Marga Pakewuh. Source: The writer's documention of a death ceremony in Wonogiri Regency, Central Java. encounter many obstacles on the way. Having tumpeng merga pakewuh for offerings in this case symbolizes the need to begin the trip.

\section{Tumpeng Obor [tumpən $\left.\mathrm{sb}^{\mathrm{h}} \mathrm{or}\right]$}

The term obor, according to the Baoesastra Djawa Dictionary (Poerwaadarminta, 1939: 449), means pring iratan, blarak, lsp. disuled dienggo colok (bamboo slices, dried coconut leaves, etc. which are lit as lighting). A torch-like object in the sense of its function as a torch is called oncor. According to Poerwadarminta (1939: 452), oncor is colok kang digawe saka bumbung lan sepadane, didokoki sumbu gedhe (lamps made of bamboo or anything which are given a large wick.

Because of the presence of oncor while serving tumpeng, the tumpeng is also known as tumpeng oncor or tumpeng obor. Mr. Sutarno (a 63-year-old modin in Pagersari RT 03 RW 6, Belikurip Village, Baturetno District) supported this idea, stating that tumpeng oncor or tumpeng obor is tumpeng served by adding oncor or obor "torch." According to this participant, this tumpeng is a symbol of the request to obtain pepadhang and means light/bright condition."

Having tumpeng obor/oncor in a death memorial or salvation ceremony as a symbol of the request to obtain pepadhang could also be an explanation for the inclusion of Islamic elements in Javanese culture. Tumpeng oncor is a symbol of lighting. When a person starts to enter the grave, the body would face a new nature. Here, yen padang dudu padange awan yen peteng dudu petenge wengi means that bright is not bright of the day, and dark is not dark of the night. That is nature's grave. Feelings of dark and bright depend on the deeds a person has done in the world.

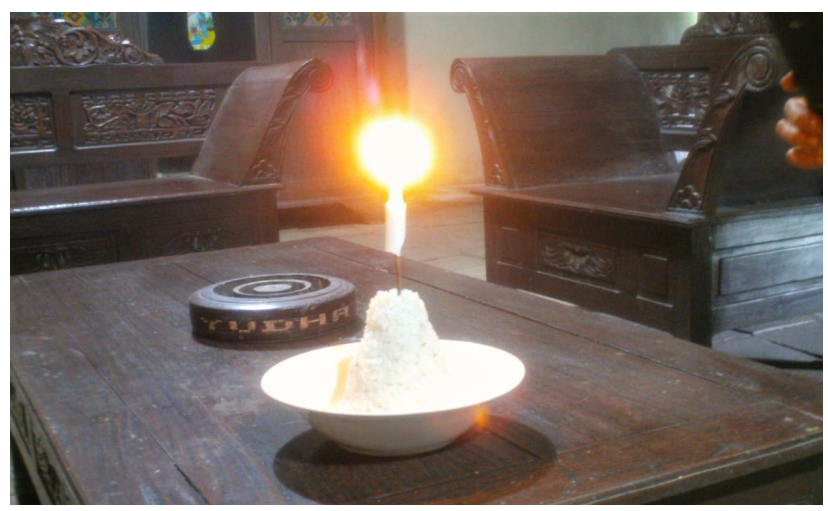

Figure 7. Tumpeng Obor. Source: The writer's documentation of a death ceremony in Wonogiri Regency, Central Java (taken in 2016). 


\section{Sega Wuduk [səg ${ }^{\mathrm{h}}$ o wuḍU?] or Sekul Suci [səkUl suci]}

In reference to Lyons's opinion (1977: 96-97), the sign in the name of sekul suci is a mark of the concept of hope for the dead to be recognized as Prophet Muhammad's (PBUH) people. Its significatum is the concrete form of sekul suci. Here, the relationship between the sign and the significatum is indirect, as presented in the figure below as a dashed line; rather, it is driven by the concept.

Sekul suci or sega wuduk/uduk is rice cooked with coconut milk. The word suci means sacred and is related to the word wuduk or wudu. Eggs could be served as side dishes (this tumpeng is called sekul suci ulamsari), but if possible, it is better to serve it with chicken broth, which is called sekul suci ulam lembaran. Literally, $u d u k$ is used to nduduk panyuwunan, meaning "making a request." Sekul suci is seen as a symbol of the prayer and the acknowledgment of the family and the perpetrator of the salvation as PBUH people, the holy or awakened Prophet Muhammad PBUH ( $m a$ 'sum), and his family and four companions: Abu Bakr, Umar, Usman, and Ali. The presentation of the sekul suci is a symbol of the hope that the deceased might be recognized as PBUH people.

On the sekul suci, there is a chicken that is cooked whole and naked. The nakedness could be identified as the servitude of a servant before God. The nakedness here is also identical to feeling open or close to being a servant of God. Nakedness means open and pure, honest with all its virtues, and it comes with a pure heart of evil intent, without the attachment of wealth, title, rank, and position - as a human being born "naked" and having nothing but the gift of God.

To add value or weight to the purity of sekul "rice" in the making or cooking of the sekul suci, the cooks are either holy or have done wudhu (ritual ablution before prayers); in this respect, there is no denying that wudhu is one of the purifying ways in the teachings of Islam.

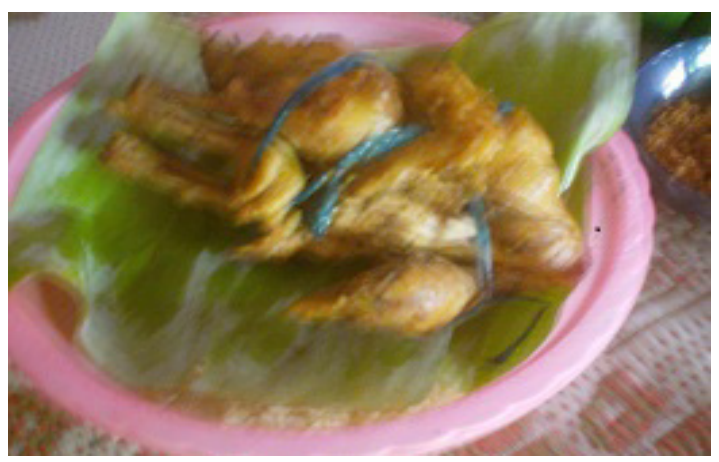

Figure 8. Sekul Suci. Source: The writer's documentation of a death ceremony in Wonogiri Regency, Central Java.

\section{Asahan [asahan] or Samiran [samiran]}

Asahan is rice shaped like a small tumpeng, but the top is blunt. Usually, every asahan is served on a plate. The numbers are even: 4, 6, 8, 10, or 12. Asahan is a flat, round clump of rice placed on a plate, tray, or encek. The symbolic meaning of asahan is that people living in this world are never free from sin; therefore, with salvation offerings, it is hoped that there will be purification or forgiveness from the Almighty for the sins (Javanese: diasahi dosane) the deceased committed while still in the world.

Asahan is also called tumpeng papak. Papak in Javanese language means "blunt." This non-pointy shape implies that people who have died no longer have ideals.

Asahan is also known as samiran because, initially, asahan was served on a sheet of samir. The word samir itself literally means rounded oval leaf cuttings with various sizes, commonly used as rice mats for salvation offerings. Samiran serves as a salvation offering to symbolize the tomb that would be the last place for the dead man in the world.

The number of asahan is jangkep, which means even, usually 4,12 , or 14 . This implies that the person has arrived "titiwanci" or is about to fulfill or finish his or her time in the world. The request is up. Asahan is equipped with side dishes, mainly in the form of meat from fourlegged animals, such as oxen or goats. The number of pieces could be one or two, and it should weigh about five kilograms, adjusted to the financial capability of the sahibul musibah, (i.e., the person who has experienced a calamity/requires salvation). This part of the ceremony is carried out so that the animal could become a ride or vehicle for the dead man or the deceased on a journey to face God.

The other side dishes are served jenggareng, (black soybeans, peanuts, and beans). Besides that, there are tempe goreng, gereh petek goreng, srundeng,

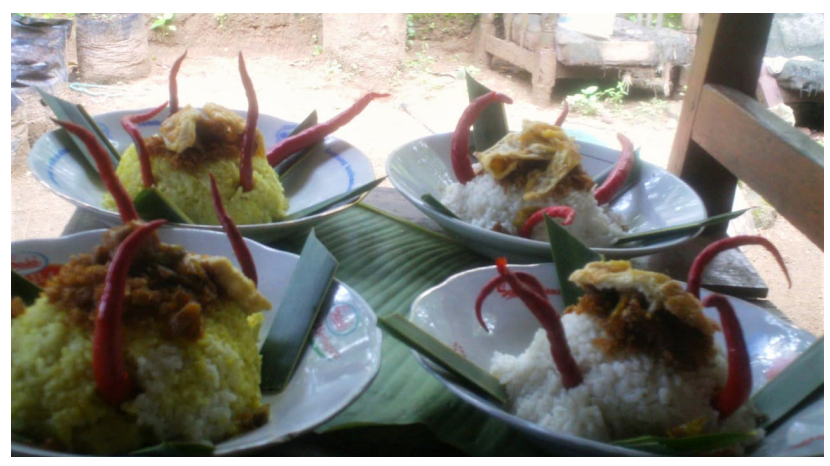

Figure 9. Asahan. Source: The writer's documentation of a death ceremony in Wonogiri Regency, Central Java (taken in 2016). 
peyek kedelai, gudeg, and sambel lombok goreng. These side dishes could also be equipped with krupuk rambak. The completeness of this side dishes symbolizes the completeness of the provisions when facing the Almighty.

Related to the serving of the asahan or samiran, the perpetrators of salvation usually say "Niki ... (mentioning the name of the deceased), kula caosi dhaharan (in the form of a samiran)." The spirit of the deceased person is believed to nyesep, or suck the food just as birds suck food. If finished, the food would be ditundung lunga ("expelled") - apa warnane wis takcawisi; ndang mulia ing alam asal asal-usulmu ("All offerings I have given; now, return to your origins"). This is in accordance with the statement explained by Mbah Inem (61 years old), a participant in Tanggung, RT 4 RW 4, Giritontro Village, Giritontro, Wonogiri.

Asahan is also called samiran. Samiran means rice that is served on samir, which are rounded oval leaf cuttings with various sizes, commonly used as rice mats for salvation offerings. Samiran serves as a salvation offering as a symbol of the tomb that would be the last place for the dead man in the world. Among the side dishes that always served together with samiran is srundheng [srund ${ }^{\mathrm{h}} \varepsilon \mathrm{E}$ ]. The words spoken when serving samiran are Pak, Bu, Nang, Nok, (or others), niki kula caosi dhaharan ("Sir, Ma'am, Miss, [or others], here I provide your favorite food").

Srundheng is made by frying or roasting grated, dried coconut. While frying it, people do not use any oil. It smells ngender, which means a fragrant scented. In the Javanese religious system, there is a belief that the fragrance of the smell of srundheng that comes out when the food is made could deliver the deceased soul to nirvana or heaven.

\section{Jenang Sepuh [j" ${ }^{\mathrm{h}}$ nạ səpUh]}

The name jenang abang putih [ $\mathrm{j}^{\mathrm{h}}$ ənan səpUh] is a sign of the concept of respect for the eldest and elderly people. The significatum itself is the shape or form of the jenang (sticky sweet snack). The relationship between sign and significatum is not directly presented as a dashed line, but is separated by a concept (Lyons, 1977: 96-97).

Jenang sepuh or jenang tuwa is jenang made from rice flour. Its semiotic meaning in the salvation ceremony/ memorial of death is in line with statements made by Mbah Mariman (71 years old) as follows.

Jenang sepuh as a symbol for the deceased's elder brother before the death because at the time of salvation took place, the person has returned to the Almighty. Hopefully, he would be given ease in the journey to face the God. (Jenang sepuh, nyumerepi sedherekipun almarhum/almarhumah ingkang sepuh piyambak sakderengipun dumadi, awit dipunsumerepi ing piyambakipun nampi timbalan saking Allah Swt.).

The cultural background of jenang sepuh offerings is that one needs to respect parents or elders. In jenang sepuh, it is conveyed penghormatan terhadap kakang kawah meaning to respect one's old brother. Javanese people highly respect others, especially to their parents, in-laws, teachers, others' parents, older siblings, and their elders. When having a meal together, for instance, as a form of respect, parents are usually invited to eat first. In family meals, parents, in this case the father, is usually asked to take his meal before the other family members. If the father is not coming home yet but is expected to eat at home later, family members usually eat rice and side dishes first and save a portion so that the father of the family will not only have leftovers to eat. This tradition is a form of respect for parents.

The elders (in Javanese: piyantun sepuh) are not only people who are already old but also people who have matured or have mature thoughts and much knowledge, such as teachers and kiai, as well as other superior people. In Javanese, there is a proverb that means "elevate the dignity and maintain his good name" (mikul dhuwur mendhem jero).

Respect for parents or elders could also be seen from the level of speech in the use of the Javanese language. In the levels of formality in the Javanese the language, aside from the level ngoko, there is also level called karma, which is also used to talk to people who are older than the speaker. According to Bastomi (1995: 46-47), in the view of Javanese people, parents, elderly

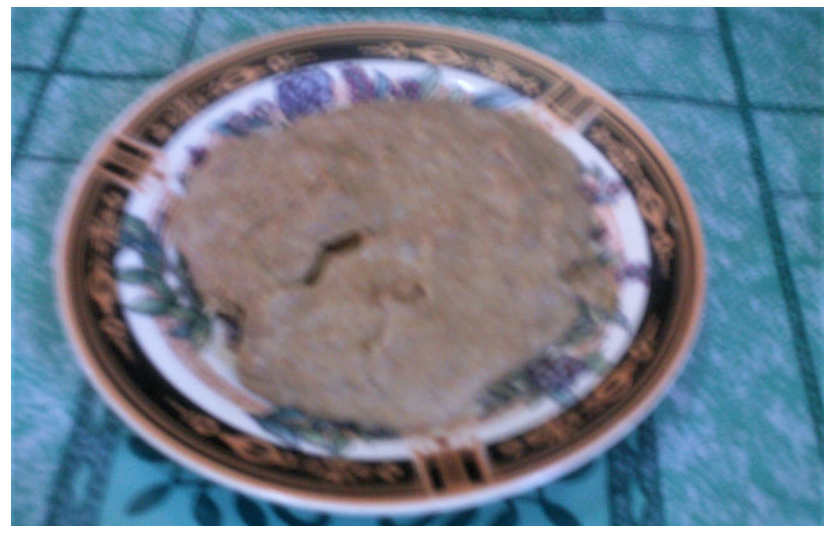

Figure 10. Jenang Sepuh. Source: The writer's documentation of a death ceremony in Wonogiri Regency, Central Java (taken in 2016). 
people, older siblings must be respected because they have eaten more salt, meaning that they have a great deal of life experience, and can also contribute to raising younger people. Older people or those who have a high position must also be respected because they have strengths, namely, the ability to regulate and lead others.

\section{CONCLUSION}

There are 10 names of food offerings in the ngesur tanah salvation ceremony-namely (1) tumpeng ungkurungkuran, (2) undur-undur, (3) tumpeng bathok bolu, (4) tumpeng gung, (5) tumpeng krumpul, (6) tumpeng marga pakewuh, (7) tumpeng obor, (8) sekul suci, (9) samiran, and (10) jenang sepuh. It could be stated that those various foods convey meanings as (1) a reminder that the person being salvaged has truly left the world; (2) as a request that the deceased soul be acknowledged as a follower of the Prophet Muhammad (PBUH), find enlightenment in the grave, and smoothly proceed on their way to God; and (3) a request that all family members (the heirs) could live harmoniously, respect each other, love one another, and gain breadth or abundance of sustenance and fortune.

On one hand, the cultural setting of the serving of food offerings whose names are explained above is a religious system of the local community. The people there believe that the deceased spirit remains alive and would be responsible for all his or her actions while living in the world. On the other hand, there is also a process of acculturation with other cultures and religions among people in the community. In conclusion, the use of language (lexicon) concerning the names of food offerings in ngesur tanah salvation reveals the views of Javanese (offerers/believers), who have been acculturated with different religions, in this case, the dominant ones being Islam and Hinduism.

\section{REFERENCES}

Ahimsa-Putra, H.S. (1985). Etnosains dan Etnometodologi: Sebuah Perbandingan. Masyarakat Indonesia, XII(2), $103-133$.

Bastomi, S. (1995). Seni dan Budaya Jawa. Semarang: IKIP Semarang Press.

Crystal, D. (1997). The Cambridge Encyclopedia of Language (Second Edition). New York: Cambridge University Press.

Djawanai, S. (2009). Telaah Bahasa, Telaah Manusia. Inauguration Speech of Professor Position at the Faculty of Cultural Sciences, Spoken in Front of the Open Meeting of the UGM Professor Council, November 4.
Duranti, Alessandro. (1997). Linguistic Anthropology. Cambridge: Cambridge University Press.

Foley, W. A. (2001). Anthropological Linguistics. Oxford: Blackwell.

Gennep, A. van. (1984). The Rites of Passage. Chicago: The University of Chicago Press.

Gunasasmita R. (2009). Kitab Primbon Jawa Serbaguna. Yogyakarta: Narasi.

Kadarisman, E.A. (2008). Hipotesis Sapir-Whorf dan Ungkap-Verbal Keagamaan. Linguistik Indonesia, 26(1), 1-21.

Kramsch, C. (1998). Language and Culture. Oxford: Oxford University Press.

Leavitt, J. (2006). Linguistic Relativities in Jourdan, C. and K.Tuite (Eds.). Language, Culture, and Society: Key Topics in Linguistic Anthropology (pp. 47-55). Cambridge, New York: Cambridge University Press.

Lyons, J. (1977). Semantics (Volume 1 and 2). Cambridge: Cambridge University Press.

Magee, B. (2001). The Story of Philosophy. Yogyakarta: Kanisius.

Mahadi, T.S.T. and S.M. Jafari. (2012). Language and Culture. International Journal of Humanities and Social Science, 2(17), 230-235.

Mahsun. (2007). Metode Penelitian Bahasa: Tahapan, Strategi, Metode, dan Tekniknya. Jakarta: PT. Raja Grafindo Persada.

Marsono. (2003). Bahasa, Sastra, Seni, dan Budaya Jawa. Inauguration Speech of Professor Position at the Faculty of Cultural Sciences, Gadjah Mada University, Yogyakarta.

Nayati, W., A.C. Zubair, M. Damami, and Sektiadi. (2016). Lelampahing Gesang (Jilid 3). Yogyakarta: Culture Office of Special Region of Yogyakarta.

Palmer, Gary B. (1999). Toward A Theory of Cultural Linguistics. Austin: University of Texas Press.

Poerwadarminta, W.J.S. (1939). Baoesastra Djawa. Groningen, Batavia: J.B. Wolters' UitgeversMaatsschappij.

Purwani, O. (2014). Javanese Power; Silent Ideology and Built Environment of Yogyakarta and Surakarta. Thesis Submitted for The Degree of Doctor of Philosophy (Ph. D.) Edinburgh: The University of Edinburgh.

Ratna, N.K. 2010. Metodologi Penelitian: Kajian Budaya dan Ilmu Sosial pada Umumnya. Yogyakarta: Pustaka Pelajar.

Sapir. Edward. (1921). Language: An Introduction to the Study of Speech. San Diego, New York, London: Harcourt Brace Jovanovich, Publishers.

Sardjananto, N. (2009). Intisari Horoskop Jawa. Yogyakarta: Kawan Kita

Spradley, J.P. (2006). Metode Etnografi (Edisi Kedua), Translated by Misbah Zulfa Elizabeth. Yogyakarta: 
Tiara Wacana.

Tjakraningrat, K.P.H. (1994). Kitab Primbon Betaljemur Adammakna (Edition: Indonesian Language), Translated by Raden Soemodidjojo. Solo: CV. Buana Raya.

Widada, Suwadji, Sukardi Mp, Gina, E. Suwatno, D.
Sutana, and U. Sidik. (2006). Kamus Bahasa Jawa (Bausastra Jawa). Yogyakarta: Kanisius.

Wierzbicka, Anna. (1997). Understanding Cultures through Their Key Words: English, Russian, Polish, German, and Japanese. Oxford and New York: Oxford University Press. 